\title{
PHOSPHORUS TRANSFORMATION IN POULTRY LITTER AND LITTER-TREATED OXISOL OF BRAZIL ASSESSED BY ${ }^{31}$ P-NMR AND WET CHEMICAL FRACTIONATION ${ }^{(1)}$
}

\author{
César Roriz de Souza ${ }^{(2)}$, Amlan Kumar Ghosh ${ }^{(3)}$, Ivo Ribeiro da Silva ${ }^{(4)}$, Elson Santiago de \\ Alvarenga ${ }^{(5)}$, Roberto Ferreira Novais ${ }^{(6)}$ \& Guilherme Luiz de Jesus ${ }^{(2)}$
}

\begin{abstract}
SUMMARY
Large quantities of poultry litter are being produced in Brazil, which contain appreciable amounts of phosphorus $(P)$ that could be of environmental concern. To assess the immediate environmental threat, five poultry litters composed of diverse bedding material were incubated for 43 days under greenhouse conditions. The litters consisted of: coffee bean husk (CH); wood chips (WC); rice husk (RH); ground corn cobs (CC) and ground napier grass (NG) (Pennisetum purpureum Schum.), in which the change in forms of soluble $P$ was evaluated using ${ }^{31} P$ NMR spectroscopy. On average, 80.2 and $19.8 \%$ of the total $P$ in the extract, respectively, accounted for the inorganic and organic forms before incubation and $48 \%$ of the organic $P$ was mineralized to inorganic $P$ in 43 days of incubation. Wide variation in the organic P mineralization rate (from $82 \%$-WC to $4 \%$ - NG) was observed among litters. Inorganic orthophosphate $(99.9 \%)$ and pyrophosphate $(0.1 \%)$ were the only inorganic $P$ forms, whereas the organic $P$ forms orthophosphate monoesters $(76.3 \%)$ and diester $(23.7 \%)$ were detected. Diester $P$ compounds were mineralized almost completely in all litters, except in the $\mathrm{CH}$ litter, within the incubation period. Pyrophosphates contributed with less than $0.5 \%$ and remained unaltered during the incubation period. Wood-chip litter had a higher organic P (40 \%) content and a higher diester: monoester ratio; it was therefore mineralized rapidly, within the first 15 days, achieving steady state by the $29^{\text {th }}$ day. Distinct mineralization patterns were observed in the litter when incubated with a clayey Oxisol. The substantial decrease observed in the organic $\mathrm{P}$ fraction (Po) of
\end{abstract}

\footnotetext{
(1) Received for publication in October 27, 2011 and approved in July 10, 2012.

(2) Students, Department of Soil (DPS), Federal University of Viçosa (UFV). Av. P. H. Rolfs, s/n. CEP 36571-000 Viçosa (MG), Brazil.

(3) Associate Professor, Department of Soil Science and Agricultural Chemistry, Institute of Agricultural Sciences, Banaras Hindu University, Varanasi-221005, India. E-mail: amlankumar@yahoo.com

(4) Associate Professor, DPS, UFV. E-mail: ivosilva@ufv.br

(5) Associate Professor, Chemistry Department, UFV.

(6) Titular Professor, DPS, UFV. E-mail: rfnovais@ufv.br
} 


\begin{abstract}
the litter types followed the order: $\mathrm{CH}(45 \%)>\mathrm{CC}(25 \%)>\mathrm{RH}(13 \%) \approx \mathrm{NG}(12 \%)>$ WC (5\%), whereas the Pi fraction increased. Incubation of RH litter in soil slowed down the mineralization of organic $P$.
\end{abstract}

Index terms: pyrophosphates, organic phosphorus, phosphorus fractionation, bedding material.

\title{
RESUMO: TRANSFORMAÇÃO DE FÓSFORO EM CAMAS DE AVIÁRIO E EM LATOSSOLO TRATADO COM CAMA DE AVIÁRIO AVALIADAS POR MEIO DE ${ }^{31} P$-RMNE FRACIONAMENTO QUÍMICO
}

\begin{abstract}
A avicultura intensiva tem se expandido bastante nos últimos anos no Brasile, com isso, gerado grandes quantidades de cama de aviário. Esses materiais contêm quantidades substanciais de fósforo $(P)$ - nutriente altamente limitante ao crescimento de plantas nos solos mais intemperizados, mas que pode causar impactos ambientais negativos se inadequadamente manejado. A fim de melhor subsidiar o uso mais sustentável desses materiais orgânicos, o presente trabalho teve como objetivo avaliar as formas e as transformações de P de camas de aviário obtidas com cinco diferentes materiais de forração do piso: casca de café, maravalha, casca de arroz, sabugo de milho triturado e capim-napier triturado. As camas de aviário foram incubadas por 43 dias, e as mudanças nas frações de $P$ foram avaliadas por meio de espectroscopia de ${ }^{31} \mathrm{P}$ RMN. Na média das cinco camas de aviário, 19,8\% do P total nos extratos encontrava-se na forma orgânica e $48 \%$ do $P$ dos compostos orgânicos foi mineralizado durante os 43 dias de incubação. Foi observada grande variação na mineralização desse nutriente entre as camas de aviário, de $4 \%$ na cama de capim-napier até $82 \%$ na cama de maravalha. Com exceção da cama de casca de café, os fostatos diéster foram quase totalmente mineralizados em todas as demais camas de aviário durante o período de incubação. $O$ ortofofato inorgânico (99,9\%) e o pirofosfato (0,1\%) foram as únicas formas de P inorgânico detectadas, enquanto o P orgânico era composto por monoéster fosfatos $(76,3 \%)$ e diéster fosfatos (23,7\%). A contribuição do pirofosfato, menor que 0,5\%, permaneceu inalterada durante o período de incubação. A cama de maravalha apresentou a maior proporção de P na forma orgânica (40\%) e maior relação $P$ diéster:P monoéster, resultando em rápida mineralização nos primeiros 15 dias de incubação, com estabilização a partir de 29 dias. Quando as camas de aviário foram incubadas com solo (Latossolo Vermelho-Amarelo), foram observados, na mineralização, distintos comportamentos entre elas. O decréscimo da fração de Pem compostos orgânicos (Po) aplicados ao solo seguiu a ordem: casca de café (45\%) > sabugo de milho $(25 \%)>$ casca de arroz $(13 \%) \approx$ capim-napier $(12 \%)>$ maravalha $(5 \%)$. Ao longo do período de incubação, foram observados incrementos no P inorgânico (Pi). A incubação da cama de casca de arroz com o solo reduziu a taxa de mineralização do seu Po. Portanto, a aplicação de cama de aviário em solos argilosos mais intemperizados pode ser uma alternativa segura de disposição e ciclagem das camas de aviário. No entanto, aplicações repetidas de doses elevadas de camas de aviário devem ser monitoradas para avaliar o risco de eutroficação de corpos de água devido ao $P$.
\end{abstract}

Termos de indexação: pirofosfatos, fósforo orgânico, fracionamento do $P$, materiais de forração.

\section{INTRODUCTION}

Brazil is the $3^{\text {rd }}$ world leading producer of chicken meat, exporting 3.65 million tons in 2008 (ABEF, 2008). The production of poultry and related products generates massive amounts of litter, consisting of a mixture of faeces, feed, feathers, and bedding materials such as straw, peanut or rice hulls and wood shavings (Gupta et al., 1997). In the past, poultry litters were mostly used as ruminant feed. Since the prohibition of their use as animal feed by Brazilian authorities in
2001, they have been mainly used as organic manure. The total production of swine and poultry manure in Brazil was estimated at 65 million tons, based on the number of swine and poultry animals in 2003 (IBGE, 2003), and since then this number has increased tremendously. This material generally contains high levels of plant macronutrients, ranging from 39 to $49 \mathrm{~g} \mathrm{~kg}^{-1} \mathrm{~N}, 3.6$ to $9.9 \mathrm{~g} \mathrm{~kg}^{-1} \mathrm{P}$, and 10 to $20 \mathrm{~g} \mathrm{~kg}^{-1} \mathrm{~K}$ (Kingery et al., 1994; Williams et al., 1999; Sauer et al., 2000). Poultry litters in the Zona da Mata in Minas Gerais contain on average $34 \mathrm{~g} \mathrm{~kg}^{-1} \mathrm{~N}, 16 \mathrm{~g} \mathrm{~kg}^{-1}$ 
$\mathrm{P}$ and $27 \mathrm{~g} \mathrm{~kg}^{-1} \mathrm{~K}$. An estimated 2.49 million tons of $\mathrm{P}$ were produced in swine and poultry manures in Brazil in 2003, which is 1.67 times the $\mathrm{P}$ used as mineral fertilizer (1.49 million tons). If the $\mathrm{P}$ used in fertilizer were replaced by swine and poultry manure, the large surplus of $\mathrm{P}$ would become an environmental concern (Shigaki et al., 2006).

One of the main environmental risks of poultry production is the imbalance of $\mathrm{N}$ and $\mathrm{P}$ in poultry manure. These two nutrients in poultry litter are not in the appropriate proportion for crops (Edwards \& Daniel, 1992; USDA-ERS, 2000). When poultry litter is applied to agricultural areas in amounts based on the recommended $\mathrm{N}$ rates, $\mathrm{P}$ is over-supplied, leading to $\mathrm{P}$ accumulation in soil (Sims et al., 2000). This $\mathrm{P}$ has the potential to leave the fields as soluble $\mathrm{P}$ in runoff water and can lead to eutrophication of water bodies (Ribaudo et al., 2003; Sharpley et al., 2007). Basically, two factors exacerbate the risk of environmental degradation caused by intensive poultry production in Brazil. Firstly, these farms are concentrated in strategically important river basins, and secondly, the region is characterized by high rainfall and wavy landscapes that can accelerate runoff and leaching losses (Ghosh et al., 2011).

Phosphorus solubility is controlled by the chemistry of liquid and solid phases of the manure matrix and the surface chemistry of inorganic and organic particulates in that environment (Lindsay, 1979). Most agricultural soils in Brazil are Oxisols, which are rich in $\mathrm{Al}$ and $\mathrm{Fe}$ oxides, capable of sorbing large amounts of P (Fontes \& Weed, 1991; Novais \& Smyth, 1999). Repeated applications of poultry litter, however, can lead to $\mathrm{N}$ and $\mathrm{P}$ accumulation and to elevated levels of one or both nutrients in surface runoff and subsurface water (McLeod \& Hegg, 1984; Sharpley \& Menzel, 1987; Kingery et al., 1994). Moreover, the amount of P loss that would cause water quality problems is usually very low, compared to the amounts required by crops or contained in typical manure or fertilizer $\mathrm{P}$ applications. For example, lake water concentrations of $\mathrm{P}$ above 0.025 $\mathrm{mg} \mathrm{L}^{-1}$ generally accelerate eutrophication. These values are an order of magnitude lower than $\mathrm{P}$ concentrations in soil solution critical for plant growth (0.2 to $\left.0.3 \mathrm{mg} \mathrm{L}^{-1}\right)$, which illustrates the vulnerability to eutrophication of fresh waters.

In recent years, there has been a rapid increase in poultry industry in the state of Minas Gerais, Brazil, and very distinct alternative bedding materials, such as coffee bean husk, corn cob, napier grass, wood chips, and rice husk have been used on broiler farms and their use is expected to increase in the near future, due to their easy availability. However, it is estimated that $50 \%$ of the litter from areas with high concentrations of poultry production facilities cannot be applied to agroecosystems in these same areas, due to environmental or economical constraints (Wimberly, 2002). This excess litter is usually stored and a time lag exists before it can be transported to other areas for application. This large quantity of manure $\mathrm{P}$, without careful management, also represents a considerable potential source of $\mathrm{P}$ losses to ground and surface waters, especially if run-off occurs during this storage period (Sherwood \& Fanning, 1981; McLeod \& Hegg, 1984; Sharpley et al., 1994).

The normally alkaline $\mathrm{pH}$ of poultry litter limits the solubility of $\mathrm{P}$ forms, especially the inorganic ones. Poultry litter acidification after field applications could result in increased $\mathrm{P}$ solubilization, thus releasing inorganic P (Tasistro et al., 2004). Oxisols are highly acidic and the $\mathrm{pH}$ of poultry litter will likely decrease after soil application, thereby releasing additional water-soluble P. Little is known about the fate of $\mathrm{P}$ applied via poultry litter with diverse bedding materials to soils with high $\mathrm{P}$ sorption capacity, as for example to the Oxisols of Brazil. The development of better management practices to optimize the recycling of manure $\mathrm{P}$ and to minimize the adverse environmental effects of animal manure application is of significant public interest. For this purpose, a better understanding of manure P chemistry is needed to determine the potential for transport of bioavailable $\mathrm{P}$ to ground and surface waters. In this study, sequential extraction and ${ }^{31} \mathrm{P}$ nuclear magnetic resonance ( $\left.{ }^{31} \mathrm{P}-\mathrm{NMR}\right)$ spectroscopy have been used to characterize $\mathrm{P}$ forms and their transformation in manure and manure applied to an Oxisol of Brazil. This technique was chosen for enabling the speciation of soil $\mathrm{P}$, which is a clear advantage over other chemical fractionation protocols.

\section{MATERIAL AND METHODS}

\section{Soil and poultry litters}

The soil used in the study was a clayey typic haplic Oxisol (Red-Yellow Latosol), sampled in Viçosa, region of Zona da Mata in Southeastern Minas Gerais, Brazil, in the Atlantic Rainforest domain (Ab'Saber, 1969). The climate is tropical with moist summers and dry, mild winters. The soil parent material is gneiss. The topography is steep with slopes from 20 to $45 \%$ and average altitudes from 200 to 1,800 m (Golfari, 1975). The soil types in the Zona da Mata are predominantly Oxisols, which are deep and well-drained, but acidic and poor in available nutrients. The most important crops are pasture and coffee, the latter often intercropped with maize and/or common bean. To minimize the influence of organic $\mathrm{P}$ in the undisturbed topsoil, soil was sampled from the subsurface layer $20-40 \mathrm{~cm}$. The samples were air-dried and ground to pass through a $2 \mathrm{~mm}$ sieve and analyzed (Embrapa, 1997). The $\mathrm{P}$ concentration in the equilibrium solution was determined by shaking samples with $\mathrm{CaCl}_{2} 0.01 \mathrm{~mol} \mathrm{~L}^{-1}$, containing $60 \mathrm{mg}$ $\mathrm{L}^{-1} \mathrm{P}$ (1:10 soil:solution ratio) (Alvarez V. et al, 2000). The maximum $\mathrm{P}$ adsorption capacity was determined 
as described by Olsen \& Watanabe (1957), following the protocol adapted by Alvarez V. \& Fonseca (1990). The main chemical and physical properties are presented in table 1.

Five types of poultry litters (PL) containing different bedding materials were used, namely: coffee bean husk $(\mathrm{CH})$; wood chips (WC); rice husk $(\mathrm{RH})$; ground corn cobs (CC) and ground napier grass (Pennisetum purpureum Schum.) (NG). These litter types were collected in poultry houses in Guiricema County, Minas Gerais, Brazil, a region in which poultry industry has expanded quickly in recent years and a great diversity of bedding materials is being used. The collected litter had been used once as bedding material for 48 days, at a bird density of $15 \mathrm{~m}^{-2}$. After collection, it was airdried, passed through a hay shredder and stored in plastic bags at room temperature until subsequent use. Litter subsamples were oven-dried at $70^{\circ} \mathrm{C}$, ground in a Wiley mill (0.5 mm sieve) and analyzed for organic carbon (Yeomans \& Bremner, 1988), total N (by dry combustion in an elemental analyzer CHNS/O 2400 (Perkin Elmer, USA). and P (by colorimetry after nitroperchloric acid digestion; Murphy \& Riley, 1962). Chemical properties of poultry litter are presented in table 2.

\section{Experiment 1. Phosphorus transformation in poultry litters evaluated with ${ }^{31}$ P-NMR spectroscopy}

The five poultry litters $(\mathrm{CH}, \mathrm{WC}, \mathrm{RH}, \mathrm{CC}$, and $\mathrm{NG)}$ were incubated for 43 days without soil, to

Table 1. Chemical and physical properties of the Oxisol under study

\begin{tabular}{lcr}
\hline Property & Unit & Value \\
\hline $\mathrm{pH} \mathrm{H}_{2} \mathrm{O}(1: 2,5)$ & & 4.80 \\
$\mathrm{Al}^{3+}$ & $\mathrm{cmol}_{\mathrm{c}} \mathrm{dm}^{-3(1)}$ & 1.10 \\
$\mathrm{Ca}^{2+}$ & $\mathrm{cmol}_{\mathrm{c}} \mathrm{dm}^{-3(1)}$ & 0.02 \\
$\mathrm{Mg}^{2+}$ & $\mathrm{cmol}_{\mathrm{c}} \mathrm{dm}^{-3(1)}$ & 0.01 \\
$\mathrm{H}+\mathrm{Al}$ & $\mathrm{cmol}_{\mathrm{c}} \mathrm{dm}^{-3(2)}$ & 6.70 \\
$\mathrm{~K}^{+}$ & $\mathrm{mg} \mathrm{dm}^{-3(3)}$ & 4.10 \\
Mehlich1-P & $\mathrm{mg} \mathrm{dm}^{-3(3)}$ & 0.30 \\
Equilibrium P & $\mathrm{mg} \mathrm{L}^{-1(4)}$ & 4.20 \\
Max. P adsorption capacity & $\mathrm{mg} \mathrm{g}^{-1(5)}$ & 2.48 \\
Organic C & $\mathrm{dag} \mathrm{kg}^{-1(6)}$ & 1.38 \\
Coarse sand & $\%^{(7)}$ & 13.00 \\
Fine sand & $\%{ }^{(7)}$ & 7.00 \\
Silt & $\%{ }^{(7)}$ & 2.00 \\
Clay & $\%{ }^{(7)}$ & 78.00 \\
Moisture at field capacity & $\mathrm{kg} \mathrm{kg}^{-1(8)}$ & 0.35 \\
\hline
\end{tabular}

${ }^{(1)}$ Extracted with $\mathrm{KCl} 1 \mathrm{~mol} \mathrm{~L}^{-1} .{ }^{(2)}$ Extracted with calcium acetate $0.5 \mathrm{~mol} \mathrm{~L}^{-1}, \mathrm{pH}$ 7.0. ${ }^{(3)}$ Extracted with Mehlich-1. ${ }^{(4)} \mathrm{P}$ concentration in solution after $1 \mathrm{~h}$ shaking with a $60 \mathrm{mg} \mathrm{L}^{-1} \mathrm{P}(1: 10$ soil:solution ratio) (Alvarez V. et al, 2000). ${ }^{(5)}$ (Olsen \& Watanabe, 1957) adapted by Alvarez V. \& Fonseca (1990). ${ }^{(6)}$ Walkley \& Black. ${ }^{(7)}$ Pipet method. ${ }^{(8)}-30 \mathrm{kPa}$. simulate the conditions in litter dumps and to study the changes in $\mathrm{P}$ forms that could be of potential environmental concern. The litters were incubated in $2 \mathrm{dm}^{3}$ plastic pots in a greenhouse $\left(30^{\circ} \mathrm{C} \pm 5\right)$ at $-33 \mathrm{kPa}$ moisture content, maintained by weighing the pots daily and replacing the lost water. Litter samples were collected at the beginning $(0 \mathrm{~d})$ and the end of the incubation period ( $43 \mathrm{~d}$ ). The WC litter was sampled more frequently (after 0, 15, 22, 29, 36 and 43 days) to monitor the complete pathway of $\mathrm{P}$ transformation. The experiment was arranged in a completely randomized block design, with three replicates.

The litter subsamples were dried at $70^{\circ} \mathrm{C}$ and stored at room temperature for ${ }^{31} \mathrm{P}-\mathrm{NMR}$ analyses. This technique was chosen because the $\mathrm{P}$ chemical species can be assessed not only in relation to their behavior in the soil, but also to their relative abundance. All $\mathrm{P}$ species in the sample may frequently be characterized without extensive sample preparation (Cade-Menun, 2005). Organic $\mathrm{P}$ compounds were extracted with a $\mathrm{NaOH}$-EDTA mixture to minimize the hydrolysis of more labile Po compounds (Turner et al., 2003). In adddition, water was also used to extract $P$ from poultry litter because water-soluble $\mathrm{P}$ (WSP) is readily released from the litter and represents a more immediate environmental concern (Sharpley \& Moyer, 2000; Vadas et al., 2004). Samples were prepared by treating $5 \mathrm{~g}$ of litter with $100 \mathrm{~mL}$ of water or $\mathrm{NaOH}$ EDTA mixture and shaken for $16 \mathrm{~h}$ at $4{ }^{\circ} \mathrm{C}$ to minimize any potential breakdown of Po compounds. Following the extraction, the samples were centrifuged for $10 \mathrm{~min}\left(509 \mathrm{~g}, 4{ }^{\circ} \mathrm{C}\right)$ and the supernatant was then filtered through Whatman 42 filter. The filtered extracts were lyophilized and stored at $-20^{\circ} \mathrm{C}$ for further analysis (usually within a week). For ${ }^{31} \mathrm{P}-\mathrm{NMR}$ spectroscopy analysis, 200 $\mathrm{mg}$ of the freeze-dried material was reconstituted in $1 \mathrm{~mL} \mathrm{NaOD}\left(0.2 \mathrm{~mol} \mathrm{~L}^{-1}\right)$ and transferred to 5 $\mathrm{mm}$ NMR tubes. The spectra were acquired in a liquid-state NMR spectrometer (Varian, Mercury $300 \mathrm{MHz}$ ) with acquisition time $1 \mathrm{sec}$, spectral width 10.000 , pulse width 6 ; delay time 0.8 number of pulses 10.000 (Turner et al., 2003), spending approximately $5 \mathrm{~h} 20 \mathrm{~min}$ for the analysis of a sample. The identification of $\mathrm{P}$ compounds was based on the chemical shift of phosphoric acid (85\% $\mathrm{v} / \mathrm{v})$. The general classes of $\mathrm{P}$ compounds and the respective chemical shifts were: phosphonates 19 ppm, inorganic orthophosphate $6.1 \mathrm{ppm}\left(\mathrm{PO}_{4}^{3-}\right)$, orthophosphate monoesters 3-6 ppm, orthophosphate diester 0.5-2 ppm; pyrophosphate 4 ppm and inorganic polyphosphates 20 ppm (Turner et al., 2003; Chen et al., 2004; Hansen et al., 2004; Leytem et al., 2008). The relative contribution of each class of $\mathrm{P}$ compounds was obtained by dividing the integrated spectral area for each band by the total integrated area. 
Experiment 2: Transformation of poultry litter-treated soil as evaluated with wet chemical fractionation

The five types of poultry litter $(\mathrm{CH}, \mathrm{WC}, \mathrm{RH}, \mathrm{CC}$ and NG) were mixed with $1.5 \mathrm{dm}^{3}$ of the clayey Oxisol at $40 \mathrm{Mg} \mathrm{ha}^{-1}$ on a dry-weight basis in plastic pots to study the transformation of $\mathrm{P}$ after litter application. The pots were incubated in a greenhouse $\left(30 \pm 5^{\circ} \mathrm{C}\right)$ and maintained at $-30 \mathrm{kPa}$, with daily replacement of water lost by evaporation. An additional treatment with wood chips only (no soil) was added to compare results with the previous study. Samples of littertreated soil were collected at the beginning (0 days) and 15 days after incubation, since in this period most $\mathrm{P}$ transformation is expected to occur (Koopmans et al., 2003). The WC litter and litter-treated soil were incubated for 43 days and sampled after 0, 15, 22, 29, 36 , and 43 days to monitor the $\mathrm{P}$ transformation kinetics. The collected samples were chemically fractionated (Bowman, 1989) into inorganic $(\mathrm{Pi})$ and organic phosphorus $(\mathrm{Po})$ fractions. The change in $\mathrm{Pi}$ and $\mathrm{Po}$ was calculated as the difference in $\mathrm{P}$ forms during the incubation period and the rate of $\mathrm{P}$ mineralization was calculated from the percentage increase in Pi during incubation per unit of Po. The experiment was set up in a completely randomized block design, with three replicates.

\section{RESULTS AND DISCUSSION}

The soil used in this study contained $78 \%$ clay, $13.8 \mathrm{~g} \mathrm{~kg}^{-1}$ organic carbon and had a high $\mathrm{P}$ fixation capacity ( $2.48 \mathrm{mg} \mathrm{P} \mathrm{g}^{-1}$ soil). The total and organic soil $\mathrm{P}$ content was 184.6 and $122.4 \mathrm{mg} \mathrm{kg}^{-1}$, respectively, and $80 \%$ of the total $\mathrm{P}$ was in organic form. Mehlich-1 available $\mathrm{P}$ was $0.3 \mathrm{mg} \mathrm{dm}^{-3}$. In Brazil, the predominance of $\mathrm{Al}$ and $\mathrm{Fe}$-rich Oxisols that can sorb large amounts of $\mathrm{P}$ has been reported (Fontes \& Weed, 1991; Novais \& Smyth, 1999). These soils occupy most of the areas under agricultural use and are therefore extremely important for crop and animal production and the overall economic viability of Brazilian agriculture (Fontes, 1996).

The chemical characteristics of the five types of poultry litters are listed in table 2 . The total $\mathrm{P}$ content in the poultry litter ranged from 13.7 to $18.1 \mathrm{~g} \mathrm{~kg}^{-1}$, with a higher $\mathrm{P}$ content and consequently lower N/P ratio in the $\mathrm{CC}$ than in the other litters. The average $\mathrm{C}$ and $\mathrm{N}$ content of the litters were 446 and $33 \mathrm{~g} \mathrm{~kg}^{-1}$, respectively, similar to the values reported elsewhere (Kingery et al., 1994; Williams et al., 1999; Sauer et al., 2000), except that the P content was considerably higher in our study. There was no significant difference in the total $\mathrm{C}, \mathrm{N}$ and $\mathrm{C} / \mathrm{N}$ ratio among the litters. The $\mathrm{P}$ of the poultry litters was fractionated to find the respective contribution of inorganic and organic to total $\mathrm{P}$. An average 61 and $39 \%$ of total $\mathrm{P}$ in the poultry litter was in inorganic and organic forms, respectively (Table 3).

Changes in $P$ forms in incubated poultry litter: ${ }^{31} \mathrm{P}-\mathrm{NMR}$ spectroscopy

Solution-state ${ }^{31} \mathrm{P}$ NMR spectroscopy was used to elucidate $\mathrm{P}$ forms in poultry litter at the beginning and end of the 43-day incubation (Figure 1). The majority of $\mathrm{P}$ analyzed was in the form of either orthophosphate or phytic acid. Similar results were reported by Leytem et al. (2008) in poultry litter with fresh pine shavings as bedding for 42 days. A strong peak at $6.1 \mathrm{ppm}$ (inorganic orthophosphate) and weaker peak area between 3-6 ppm (orthophosphate monoesters) and -0.5 - 2 ppm (orthophosphate diester) were observed in this study after incubation for 43 days, indicating mineralization of organic to inorganic $\mathrm{P}$ forms. In some litters, a complete peak absence at 0.5 to $2 \mathrm{ppm}$ after incubation suggested complete mineralization of diester P (Figure 1 and Table 4). The more intensive mineralization of orthophosphate diesters may be attributed to the presence of compounds such as phospholipids, nucleic acids and sugar phosphates (Turner \& McKelvie, 2002). Their

Table 2. Total organic C (TOC), nitrogen (N), phosphorus $(\mathrm{P})$ concentration, and $\mathrm{C} / \mathrm{N}, \mathrm{C} / \mathrm{P}$ and $\mathrm{N} / \mathrm{P}$ molar ratios in five types of poultry litters

\begin{tabular}{lcccccc}
\hline Poultry litter type & TOC & N & P & C/N & C/P & N/P \\
\hline & \multicolumn{7}{c}{ g kg $^{-1}$} \\
\cline { 2 - 7 } Coffee bean husk & $391 \mathrm{a}$ & $32.8 \mathrm{a}$ & $14.4 \mathrm{~b}$ & 13.9 & 70.0 & 5.0 \\
Ground corn cob & $510 \mathrm{a}$ & $34.2 \mathrm{a}$ & $18.6 \mathrm{a}$ & 17.4 & 70.7 & 4.1 \\
Wood chip & $391 \mathrm{a}$ & $30.9 \mathrm{a}$ & $13.7 \mathrm{~b}$ & 14.8 & 73.6 & 5.0 \\
Rice husk & $491 \mathrm{a}$ & $34.7 \mathrm{a}$ & $15.9 \mathrm{~b}$ & 16.5 & 79.6 & 4.8 \\
Ground napier grass & $449 \mathrm{a}$ & $34.8 \mathrm{a}$ & $15.1 \mathrm{~b}$ & 15.0 & 76.7 & 5.1 \\
Mean & 446 & 33.0 & 16.0 & 13.3 & 28.8 &
\end{tabular}

Means followed by the same letter within each column do not differ by Tukey's test $(p=0.05)$.

Table 3. Total, inorganic (Pi), organic (Po) $\mathbf{P}$ concentration and relative contribution of $P o$ in poultry litters

\begin{tabular}{lcclc}
\hline Poultry litter type & Total P & Pi & Po & Po contribution \\
\hline & \multicolumn{4}{c}{$\mathrm{g} \mathrm{kg}^{-1}$} \\
\cline { 2 - 4 } Coffee bean husk & $14.4 \mathrm{c}$ & $9.8 \mathrm{c}$ & $4.7 \mathrm{~b}$ & $\%$ \\
Ground corn cob & $18.2 \mathrm{~b}$ & $10.8 \mathrm{bc}$ & $7.4 \mathrm{ab}$ & 40 \\
Wood chip & $17.1 \mathrm{c}$ & $10.5 \mathrm{bc}$ & $6.7 \mathrm{ab}$ & 39 \\
Rice husk & $21.9 \mathrm{a}$ & $13.1 \mathrm{a}$ & $8.8 \mathrm{a}$ & 40 \\
Ground napier grass & $19.0 \mathrm{ab}$ & $10.9 \mathrm{~b}$ & $8.0 \mathrm{ab}$ & 42 \\
Mean & 18.1 & 11.0 & 7.1 & 39
\end{tabular}

Means followed by the same letter within each column do not differ by Tukey's test $(p=0.05)$. 
0 d-incubation
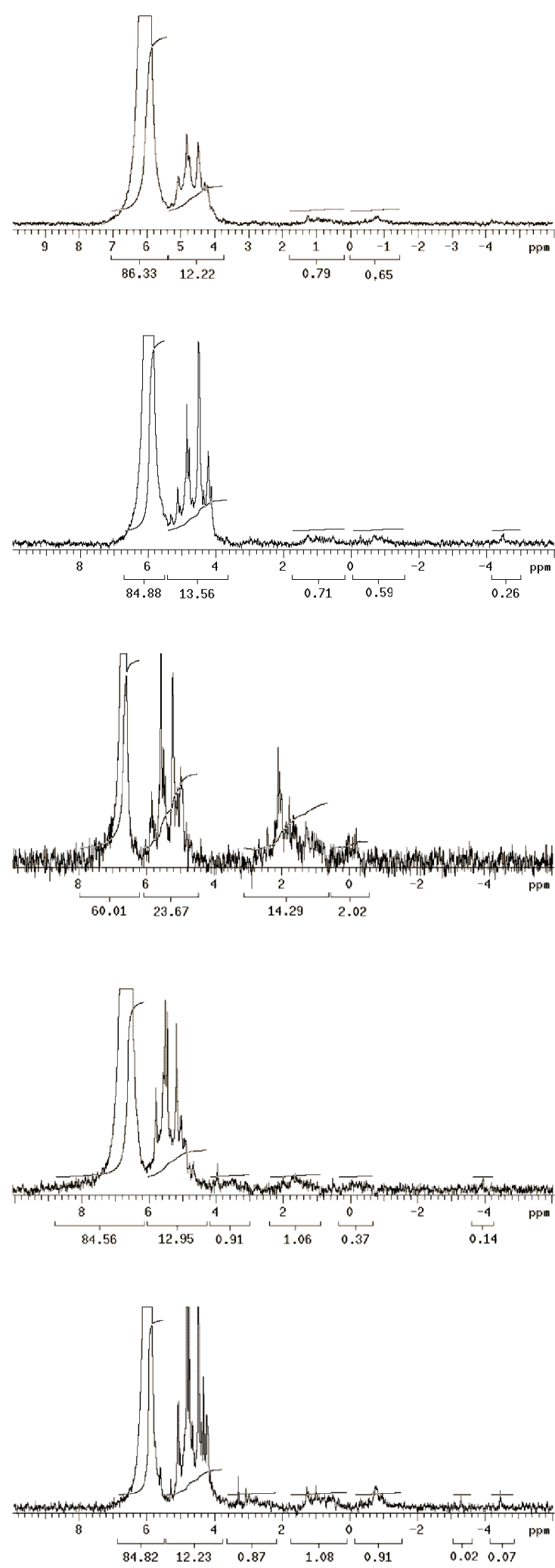

43 d-incubation

CS

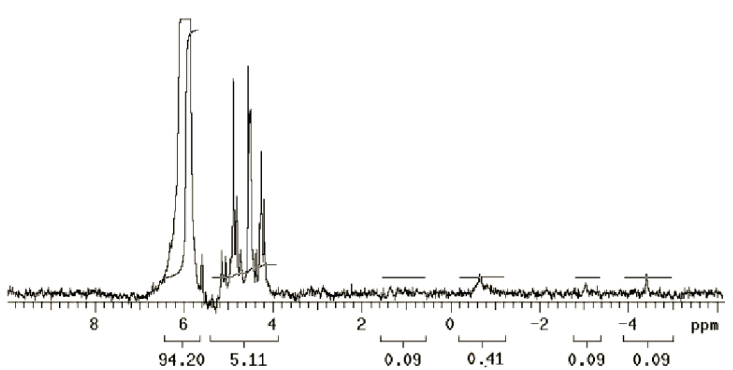

$\mathrm{CC}$

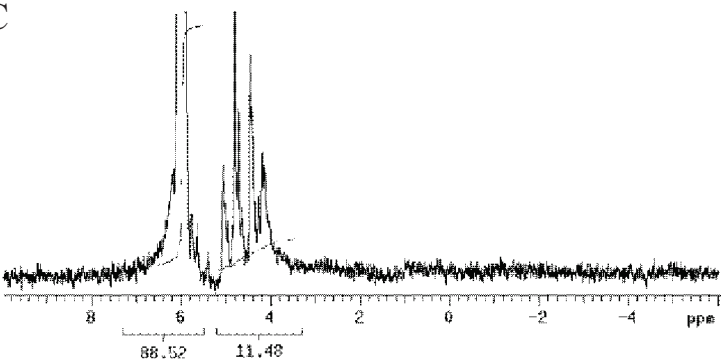

WC

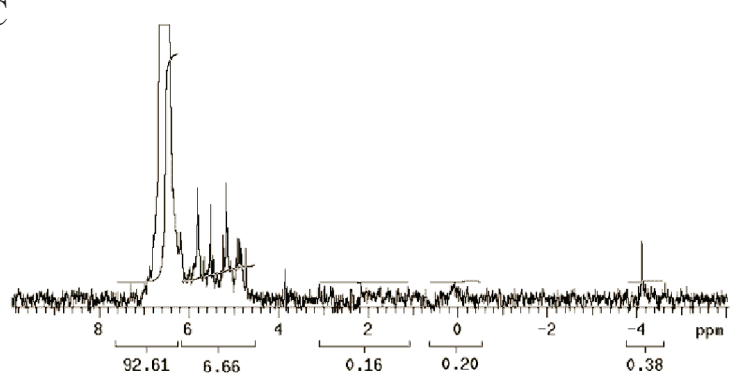

RH

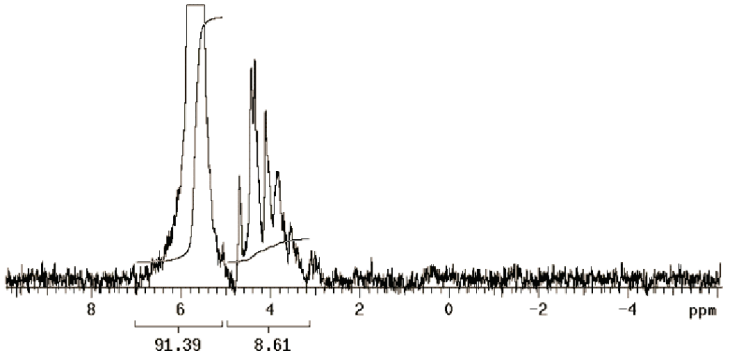

NG

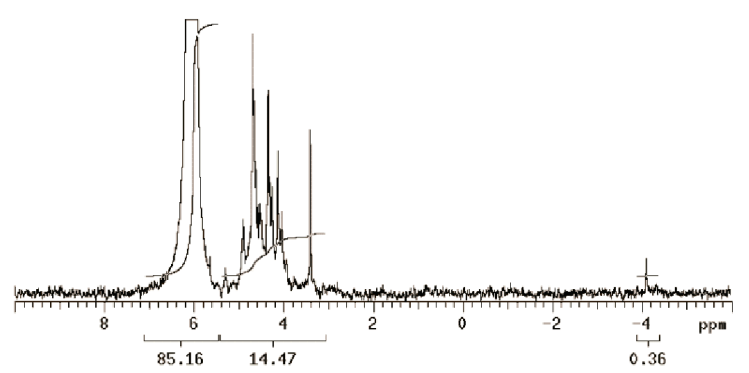

Figure 1. ${ }^{31} \mathrm{P}-\mathrm{RMN}$ spectra of water-soluble $\mathrm{P}$ compounds found in poultry litters 0 and 43 days after incubation. 
low charge density reduces the energy of interaction with soil colloids and they become more easily accessible to decomposers (Turrión et al., 2001). In semi-arid Northern Tanzania, clearing and continuous low input agriculture reduced both organic and inorganic $\mathrm{P}$ in the soil. Homestead cultivation led to a $53 \%$ depletion of orthophosphate diester $\mathrm{P}$, whereas only 30 and $39 \%$ reduction of orthophosphate monoester $\mathrm{P}$ occurred after 3 and 15 years of cultivation, respectively (Solomon \& Lehman, 2000). Thus, despite the smaller proportion of orthophosphate diesters, they may be a more readily available $\mathrm{P}$ source to plants than the dominant orthophosphate monoesters (Hayes et al., 2000).

The $\mathrm{P}$ distribution in the poultry litter extracts was calculated by integrating the signal areas, and $\mathrm{P}$ concentrations were computed by multiplying the proportion of the total spectral area assigned to a specific signal by the total $\mathrm{P}$ concentration in the original extract (Table 4). On average, 80.2 and $19.8 \%$ of the total $\mathrm{P}$ in the extract was distributed in inorganic and organic forms before incubation. After 43 days of incubation, Pi increased to $90.4 \%$ and $\mathrm{Po}$ decreased to $9.5 \%$. This very large quantity of inorganic $\mathrm{P}$, without careful management, also represents a potential threat as source of $\mathrm{P}$ losses to ground and surface waters by incidental losses through surface and sub-surface flow, directly after surface application or indirectly, by soil $\mathrm{P}$ enrichment (Smith et al., 2001). P loss in surface run-off from livestock manures has been shown to depend not only on the rate and timing of manure application but also, more importantly, on the interval between the application and the run-off event (Sherwood \& Fanning, 1981; McLeod \& Hegg, 1984; Sharpley et al., 1994).

In the $\mathrm{Pi}$ fraction, the main component was inorganic orthophosphate (99.9\%) and the remaining small proportion was pyrophosphate $(0.1 \%)$, whereas in the organic $\mathrm{P}$ fraction, orthophosphate monoesters predominated (76.3\%), which contributed to $15.1 \%$ of total P, while the orthophosphate diesters represented $4.7 \%$ of the total P. Among the organic $\mathrm{P}$ compounds, monoesters have been reported to be predominant (Dalal, 1977). Our results are similar to those reported by Koopmans et al. (2003) for poultry litter, who found that $78.5 \%$ of total $\mathrm{P}$ was in inorganic (Pi) forms (77\% inorganic orthophosphate and $1.5 \%$ pyrophosphate) and $21.5 \%$ was $\mathrm{P}$ in organic forms $(17.9 \%$ monoester phosphates, $0 \%$ diester phosphates and $3.6 \%$ aromatic diester phosphates).

Among the evaluated litter types, the WC litter differed from the others with a lower inorganic (60\%) and higher organic $\mathrm{P}(40 \%)$ content. It also contained the highest proportion of orthophosphate monoesters $(23.7 \%)$ and the largest proportion of orthophosphate diesters (16.3\%) among the litters studied (Figure 1 and Table 3). The WC litter also had a considerably higher diester: monoester ratio than the others. Diester phosphates, although found in small amounts, are reported to be chemically more labile than monoester P (Tate \& Newman, 1982), with higher susceptibility to microbial or enzyme attack in the soil environment (Dai et al., 1996). Because the monoester is considered more stable and less accessible to plants than diester, the diester: monoester ratio is a measure of organic P lability (Chapuis-Lardy et al., 2001; Turrión et al., 2001).

The incubation of WC litter samples was observed in detail (Figure 2). It was found that Po mineralization was highest in the first $15 \mathrm{~d}$, achieving steady-state by the $29^{\text {th }}$ day. The increase in inorganic orthophosphate was concomitant to the decrease in orthophosphate monoesters and diesters. Pyrophosphate was present at a low proportion and remained unaltered. Phosphonates and polyphosphates were not detected in the analyzed samples.

The measurement of net Po mineralization is complicated by the high reactivity of released inorganic $\mathrm{P}$ with the soil solid phase. However, since only poultry litters with similar $\mathrm{C} / \mathrm{N}$ ratios were studied, a similar adsorption of the released $\mathrm{Pi}$ and calculated gross $\mathrm{Po}$

Table 4. ${ }^{31} \mathrm{P}-\mathrm{NMR}$-based relative $\mathrm{P}$ distribution in distinct inorganic ( $\mathrm{Pi}$ ) and organic ( $\left.\mathrm{Po}\right) \mathrm{P}$ forms in poultry litter before and after 43d-incubation, and relative mineralization of the Po forms (MPo)

\begin{tabular}{|c|c|c|c|c|c|c|c|c|c|c|c|}
\hline \multirow{3}{*}{ Poultry litter } & \multicolumn{4}{|c|}{0 day } & \multicolumn{4}{|c|}{43 days } & & & \multirow{3}{*}{ MPo } \\
\hline & \multicolumn{2}{|c|}{$\mathbf{P i}$} & \multicolumn{2}{|c|}{ Po } & \multicolumn{2}{|c|}{$\mathbf{P i}$} & \multicolumn{2}{|c|}{ Po } & \multicolumn{2}{|c|}{ Change } & \\
\hline & $\operatorname{Ort}^{(1)}$ & Pyro $^{(2)}$ & $\operatorname{Mon}^{(3)}$ & $\operatorname{Dies}^{(4)}$ & Ort & Pyro & Mon & Dies & Mon & Dies & \\
\hline & \multicolumn{10}{|c|}{$\%$} & \\
\hline Coffee bean husk & 86.3 & 0.0 & 12.2 & 1.5 & 94.2 & 0.2 & 5.1 & 0.5 & 58 & 67 & 59.1 \\
\hline Ground corn cob & 84.9 & 0.2 & 13.6 & 1.3 & 88.5 & 0.0 & 11.5 & 0.0 & 15 & 100 & 22.8 \\
\hline Wood chip & 60.0 & 0.0 & 23.7 & 16.3 & 92.6 & 0.3 & 6.7 & 0.4 & 72 & 97 & 82.3 \\
\hline Rice husk & 84.6 & 0.1 & 13.9 & 1.4 & 91.4 & 0.0 & 8.6 & 0.0 & 38 & 100 & 43.8 \\
\hline Ground napier grass & 84.8 & 0.1 & 12.2 & 2.9 & 85.2 & 0.4 & 14.5 & 0.0 & 0 & 100 & 4.63 \\
\hline Mean & 80.1 & 0.1 & 15.1 & 4.7 & 90.4 & 0.2 & 9.3 & 0.2 & 38 & 96 & 42.5 \\
\hline
\end{tabular}

(1) Ort: Orthophosphate; ${ }^{(2)}$ Pyro: pyrophosphate; ${ }^{(3)}$ Mon: monoester P; ${ }^{(4)}$ Dies: diester P. 


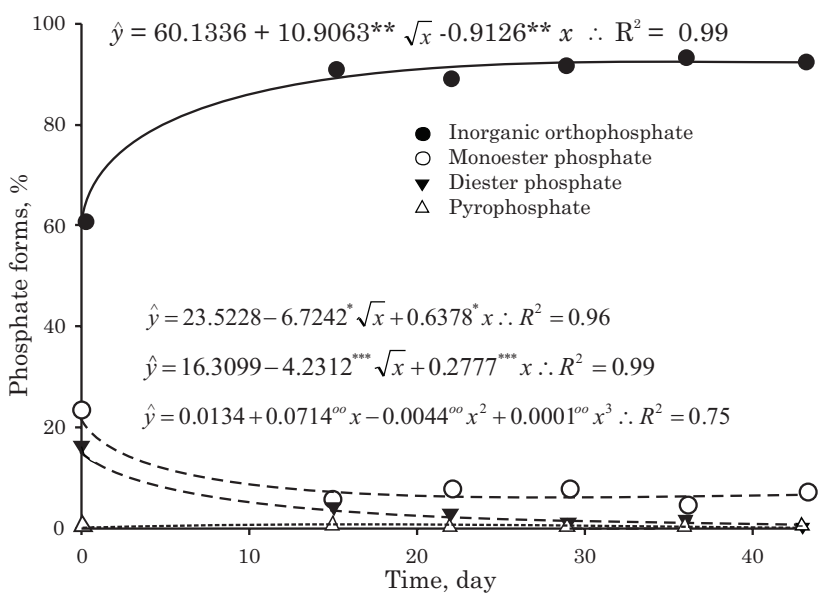

Figure 2. Dynamics of $P$ fractions in wood chip-based poultry litter during the 43-d incubation period. $* * *, * *, *$, and 0 indicate that coefficients are significant at $0.1,1,5$ and $10 \%$, respectively.

mineralization was assumed (Preusch et al., 2002). There was a wide variation in the organic $\mathrm{P}$ mineralization rate observed among litters; the highest mineralization ( $82 \%$ ) was detected in WC, followed by $\mathrm{CH}(59 \%), \mathrm{RH}(43 \%), \mathrm{CC}(22 \%)$ and the lowest in NG (4\%). This trend followed the decrease in monoester content before and after incubation. Comparing the litter types, it was observed that in the CC, RH and NG litters, $100 \%$ of orthophosphate diesters was mineralized during the $43 \mathrm{~d}$-incubation, whereas in the $\mathrm{CH}$ and WC litters, 67 and $97 \%$ of orthophosphate diesters, respectively, were mineralized.

Results of this study indicate that poultry litter contains a considerable a mount of soluble $\mathrm{Pi}$, which increases during incubation. Even WC litter, which initially contained less $\mathrm{Pi}$, was rapidly mineralized during the incubation period and produced $\mathrm{Pi}$ equivalent to other litter types. Readily bio-available inorganic $\mathrm{P}$ represents a potential threat of leaching and runoff losses in the case of rainfall. Water-soluble $\mathrm{Po}$ is also mobile in the soil profile (Anderson \& Magdoff, 2004). The open dumping of poultry litter or repeated applications of high poultry litter rates should therefore be avoided to minimize environmental risks of $\mathrm{P}$ contamination of fresh water bodies.

\section{Soil-litter incubation study: chemical fractionation}

The chemical fractionation of litter using Bowman's fractionation scheme (Bowman, 1989) revealed that the concentration of $\mathrm{Pi}$ was higher in the $\mathrm{RH}$ litter and lowest in the $\mathrm{CH}$ litter, but did not differ from Pi in the WC and CC litters (Table 3). The same pattern was observed for the Po concentration. The Pi was the dominant fraction, corresponding to an average of $61 \%$ of total $\mathrm{P}$. The smallest proportion of $\mathrm{Po}$ was found in the $\mathrm{CH}$ litter (32\%) and the highest in the NG litter (42\%). The results found here show that a substantial proportion (39\%) of $\mathrm{P}$ present in the poultry litters is in organic forms, which is higher than the 21\% Po reported by Peperzak et al. (1959) and $25 \%$ reported by Cassol et al. (2001) in Southern Brazil, based on Hedley's fractionation scheme (Hedley et al., 1982). Using a similar fractionation procedure, Sharpley \& Moyer (2000) however reported the contribution of a Po fraction of $9 \%$ of total $\mathrm{P}$ in a litter consisting of pine bark (three lots raised, 1.31 birds $\mathrm{m}^{-2}$ ). In the last decade, several methods have been used to characterize the different $\mathrm{P}$ forms in soils and animal manures (Hedley et al., 1982; Bowman, 1989; Dou et al., 2000; Sharpley \& Moyer, 2000).These differences might be due to the distinct methods used in the assessment of $\mathrm{P}$ fractions (Koopmans et al., 2003), as well as the bird's diet, origin and management of the litters (Maguire et al., 2006).

The distribution of $\mathrm{P}$ fraction at the beginning ( 0 days) of the incubation period revealed no difference in the Po concentration among the poultry litters (Table 5). However, the litter differed in relation to the Pi concentration, which was highest in the $\mathrm{RH}$ litter and lowest in $\mathrm{CH}$ litter. The Pi concentrations in the other litters were intermediate. After 15 days of incubation with a clayey Oxisol, there was a substantial decrease in the Po fraction and an increase in the Pi fraction (Table 5). The litter with the highest relative decrease in $\mathrm{Po}$ was the $\mathrm{CH}$ litter (45\%) followed by the CC (25\%), RH (13\%), NG (12\%) and WC (5\%). However, no concomitant increase in Pi was observed in the CC litter, probably because of transformation to un-extractable forms in the soil.

The smallest decrease in Po and consequently smallest increase in $\mathrm{Pi}$ was observed in WC litter. Although the $\mathrm{C} / \mathrm{N}$ and $\mathrm{C} / \mathrm{P}$ molar ratios were similar as in the other poultry litters, factors such as elevated concentration of lignin and phenolic compounds present in the wood chips may have limited the decomposer activity of soil microorganisms (Oglesby \& Fownes, 1992; Entry \& Backman, 1982; Cortez et al., 1996). Possibly, high concentrations of orthophosphate monoesters, such as inositol hexaphosphate (phytic acid), with a high affinity for the soil colloids (Leytem et al., 2002; Gebrim et al., 2004), could have reduced the availability to soil microbes and thus decreased decomposition (Bowman \& Cole, 1978; Evans, 1985; Turner \& McKelvie, 2002). It is suspected that this phenomenon may favor the persistence of $\mathrm{P}$ in organic compounds for a longer period of time and be more prone to be transported to water bodies (Eghball et al., 1996; Chardom et al., 1997), increasing the risk of eutrophication.

The RH litter was incubated for a longer period (43 d) with and without soil (Figure 3). It was found that in the absence of soil, Po mineralization was higher in the first 15 days of incubation, with about $50 \%$ of Po being mineralized (Figure 3a). Afterwards, the mineralization rates tended to stabilize. The 
Table 5. Change in phosphorus (P) fractions of poultry litter incubated with soil

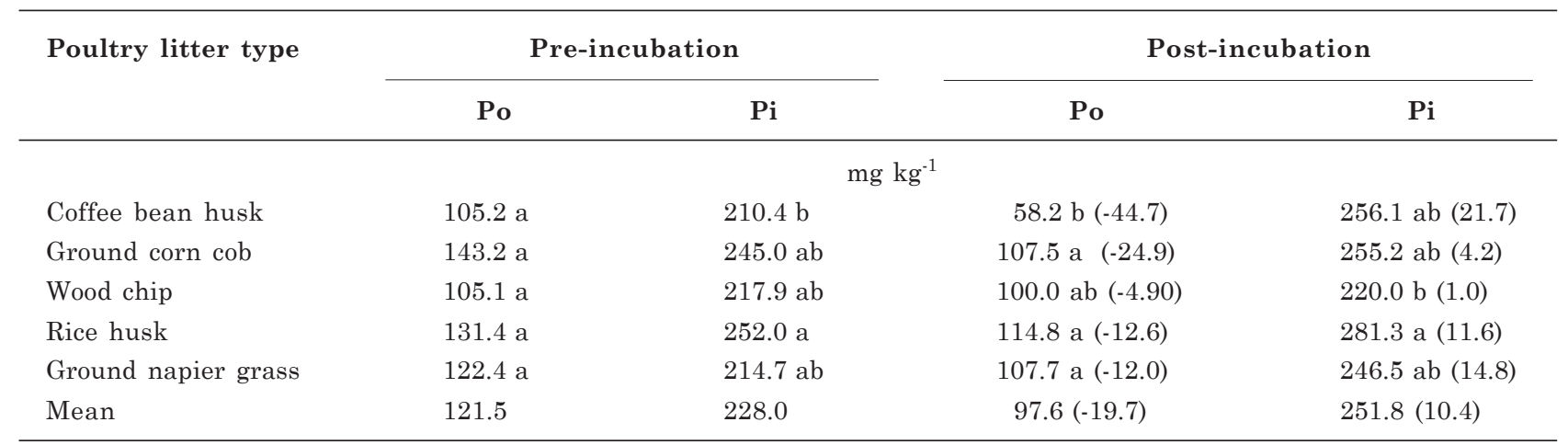

Numbers in parentheses represent the relative change in comparison to the pre-incubation period. Means followed by the same letter within each column do not differ by Tukey's test $(\mathrm{p}=0.05)$.

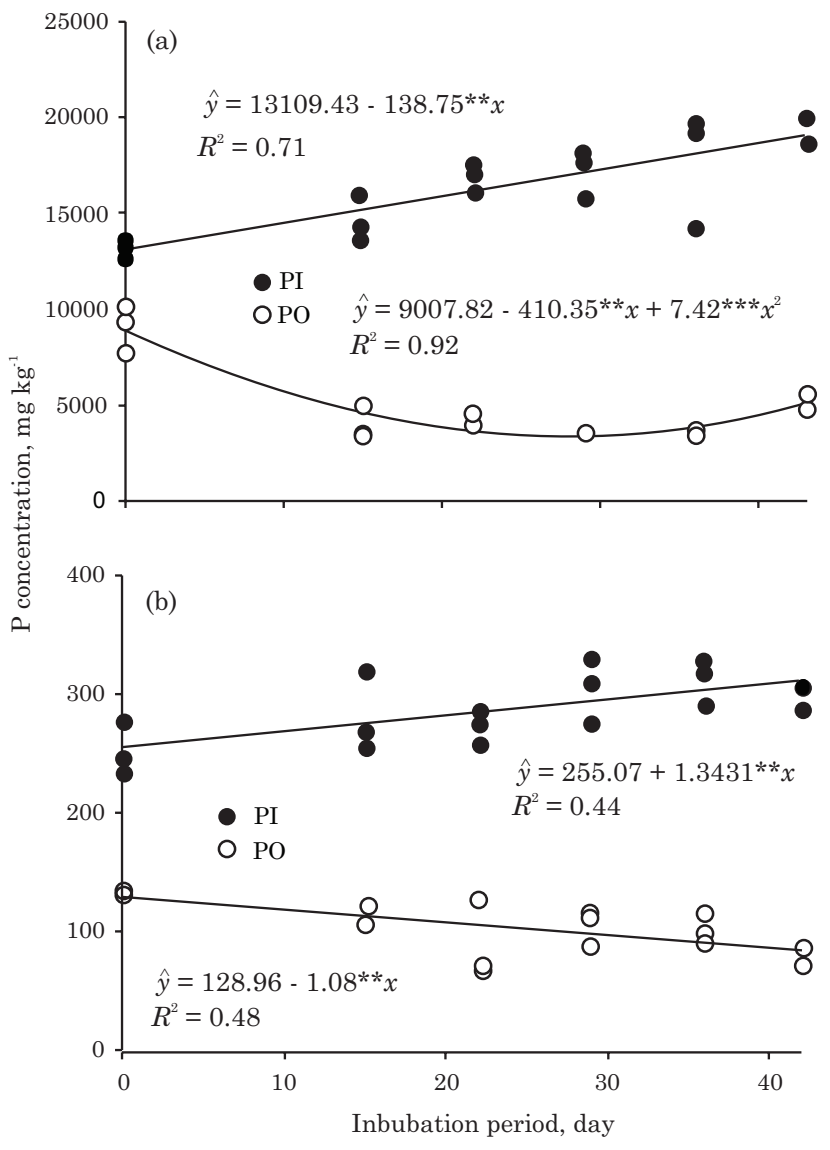

Figure 3. Organic (Po) and inorganic (Pi) $P$ concentration in the rice husk-based poultry litter incubated without (a) and with (b) soil. ****, *** * indicate that regression coefficients are significant at $0.1,1$, and $5 \%$, respectively.

reduction in the Po mineralization rate after 15 days of incubation was possibly due to the high buildup of $\mathrm{Pi}$, inhibiting microbial activity (Bahl \& Toor, 2002). On the other hand, when RH litter was incubated with soil, the decrease in Po concentration was linear and slower (Figure 3b). At the end of the incubation period, the proportion of Po decreased by $41 \%$ (decreased from 34 to $20 \%$ ) when incubated with soil and by $49 \%$ (decreased from 41 to $21 \%$ ) when incubated without soil. The decrease in the Po mineralization rate in soil could possibly be due to a protection of organic phosphate compounds by adsorption on soil colloids (Cross \& Schlesinger, 1995; Turrión et al., 2001; Conte et al., 2003), leading to the preferential preservation of some Po forms, especially orthophosphate monoesters (Koopmans et al., 2003). Pi increased linearly, irrespective of whether the RH litter was incubated with or without soil. However, the slope of the curve was steeper for incubation without soil, indicating quicker mineralization in the absence of soil.

Results of the chemical fractionation indicate distinct patterns of Po mineralization among litter types. The WC and $\mathrm{CH}$ litters, with fast $\mathrm{Po}_{0}$ mineralization, could be used to fertilize rapidly growing crops, with a high initial $\mathrm{P}$ demand. On the other hand, the CC and GN litter, with a slower Po mineralization rate, would better meet the demands of perennial crops or plants with a smaller initial $\mathrm{P}$ demand. Although some organic P forms, such as phytic acid, are more stable in the soil environment (Turner \& McKelvie, 2002), it appears that some perennial plants are able to acquire them. Chen et al. (2004) reported that pine (Pinus radiata) trees are able to acquire $\mathrm{P}$ from phytic acid from soils, but faster-growing plants, including some annual grasses and legumes, are not efficient in acquiring $\mathrm{P}$ from such organic sources (Hayes et al., 2000).

\section{CONCLUSIONS}

1. Inorganic orthophosphate is the dominant species found in the water-soluble fraction of the poultry litters, but a portion of $\mathrm{P}$ in the poultry litters also occurs as organic forms. 
2. There is a large variation among poultry litters in terms of the organic $\mathrm{P}$ mineralization rate in the the 43-day incubation period; the highest decomposition was $82 \%$ for wood chip and the lowest $4 \%$ for napier grass litter.

3. Among the organic $\mathrm{P}$ forms, the monoesters are predominant, but diester $\mathrm{P}$ forms are also present and are more rapidly mineralized. The mineralization rate of organic $\mathrm{P}$ in poultry litter is rapid in the first 15 days after incorporation into the soil and then slows down.

4. A higher mineralization rate of organic $\mathrm{P}$ was observed in the poultry litters, without soil.

\section{ACKNOWLEDGEMENTS}

Dr. Amlan Kumar Ghosh wishes to thank CNPq and TWAS for financial support and for a scholarship at the Federal University of Viçosa, MG, Brazil. Additional financial support was provided by FAPEMIG and CNPq. Finally, we are indebted to the Assistant Editor and three anonymous reviewers for their constructive suggestions.

\section{LITERATURE CITED}

AB'SABER, A. Domínios morfoclimáticos do Brasil. Orientação, 3:55-71,1969.

ALVAREZ V., H.V. \& FONSECA, D.M. Definition of phosphorus levels for determining the maximum capacity of phosphate adsorption and for greenhouse experiments. R. Bras. Ci. Solo, 14:49-55, 1990.

ALVAREZ V., H.V.; NOVAIS, R.F.; DIAS, L.E. \&. OLIVEIRA, J.A. Determinação e uso do fósforo remanescente. B. Inf. SBCS, 25:24-32, 2000 .

ANDERSON, B.H. \& MAGDOFF, F.R. Relative movement and soil fixation of soluble organic and inorganic phosphorus. J. Environ. Qual., 34:2228-2233, 2005.

ASSOCIAÇÃO BRASILEIRA DOS PRODUTORES E EXPORTADORES DE FRANGOS - ABEF. Relatório Anual, 2008. Available: <http://www. abef.com.br> Acessed May 9, 2010.

BAHL, G.S. \& TOOR, G.S. Influence of poultry manure on phosphorus availability and the standard phosphate requirement of crop estimated from quantity-intensity relationship in different soils. Biores. Technol., 85:317$322,2002$.

BOWMAN, R.A. \& COLE, C.V. Transformations of organic phosphorus substrates in soils as evaluated by $\mathrm{NaHCO}_{3}$ extraction. Soil Sci., 125:49-54, 1978.

BOWMAN, R.A. A sequential extraction procedure with concentrated sulfuric acid and dilute base for soil organic phosphorus. Soil Sci. Soc. Am. J., 53:362-366, 1989.
CADE-MENUN, B. Using phosphorus-31 nuclear magnetic resonance spectroscopy to characterize organic phosphorus in environmental samples; In: TURNER, B.; FROSSARD, E. \& BALDWIN, D.S., eds. Organic phosphorus in the environment. Cambridge, CABI Publishing, 2005. p.21-44.

CASSOL, P.C.; GIANELLO, C. \& COSTA, V.E.U. Frações de fósforo em estrumes e sua eficiência como adubo fosfatado. R. Bras. Ci. Solo, 25:635-644, 2001.

CHAPUIS-LARDY, L.; BROSSARD, M. \& QUIQUAMPOIX, H. Assessing organic phosphorus status of Cerrado Oxisols (Brazil) using ${ }^{31} \mathrm{P}-\mathrm{NMR}$ spectroscopy and phosphomonoesterase activity measurement. Can. J. Soil Sci., 81:591-601, 2001.

CHARDOM, W.J.; OENEMA, O.; DEL CASTILHO, P.; URIESEMA, R.; JAPENGA, J. \& BLAAUW, D. Organic phosphorus in solution and leachates from soils treated with animal slurries. J. Environ. Qual., 26:372-378, 1997.

CHEN, C.R.; CONDRON, L.M.; TURNER, B.L.; MAHIEU, N.; DAVIS, M.R.; XU, Z.M. \& R.R. SHERLOCK. Mineralization of soil orthophosphate monoesters under pine seedlings and ryegrass. Aust. J. Soil Res., 42:189196, 2004.

CONTE, E.; ANGHINONI, I. \& RHEINHEIMER, D.S. Frações de fósforo acumuladas em Latossolo argiloso pela aplicação de fosfato no sistema plantio direto. R. Bras. Ci. Solo, $27: 893-900,2003$

CORTEZ, J.; DEMARD, J.M.; BOTTNER, P. \& MONROZIER, L.J. Decomposition of Mediterranean leaf litters: A microcosm experiment investigating relationships between decomposition rates and litter quality. Soil Biol. Biochem., 28:443-452, 1996.

CROSS, A.F. \& SCHLESINGER, W.H. A literature review and evaluation of the Hedley fractionation: applications to the biogeochemical cycle of soil phosphorus in natural ecosystems. Geoderma, 64:197-214, 1995.

DAI, K.H.; DAVID, M.B.; VANCE, G.F. \& KRYSZOWSKA, A.J. Characterization of phosphorus in a spruce-fir Spodosol by phosphorus-31 nuclear magnetic resonance spectroscopy. Soil Sci. Soc. Am. J., 60:1943-1950, 1996.

DALAL, R.C. Soil organic phosphorus. Adv. Agron., 29:83$117,1977$.

DOU, Z.; TOTH, J.D.; GALLIGAN, D.T.; RAMBERG JR., C.F. \& FERGUSON, J.D. Laboratory procedures for characterizing manure phosphorus. J. Environ. Qual., 29:508-514, 2000

EDWARDS, D.R. \& DANIEL, T.C. Environmental impacts of on-farm poultry waste disposal - A review. Biores. Technol., 41:9-33, 1992.

EGHBALL, B.; BENFORD, G.D. \& BALTENSPERGER, D.D. Phosphorus movement and adsorption in a soil receiving long-term manure and fertilizer application. J. Environ. Qual., 25:1339-1343, 1996.

EMPRESA BRASILEIRA DE PESQUISA AGROPECUÁRIA EMBRAPA. Manual de métodos de análise de solos. Rio de Janeiro, 1997. 212p. 
ENTRY, J.A \& BACKMAN, C.B. Influence of carbon and nitrogen on cellulose and lignin degradation in forest soils. Can. J. For. Res., 19:723-734, 1982.

EVANS, A.J. The adsorption of inorganic phosphate by a sand soil as influenced by dissolved organic compounds. Soil Sci., 140:251-255, 1985.

FONTES, M.P.F. Phosphate adsorption by clays from Brazilian Oxisols: Relationship with specific area and mineralogy. Geoderma, 72:31-51, 1996.

FONTES, M.P.F. \& WEED, S.B. Iron oxides in selected Brazilian Oxisols: I. Mineralogy. Soil Sci. Soc. Am. J., 55:1150-1155, 1991.

GEBRIM, F.O.; SILVA, I.R.; JESUS, G.L. \& NOVAIS, R.F. Adsorção competitiva de ortofosfato e hexafosfato de inositol em Latossolos sob influência da calagem. In: REUNIÃO BRASILEIRA DE FERTILIDADE DO SOLO E NUTRIÇÃO DE PLANTAS, 26., Lages, 2004. Anais... Lages, FERTBIO, 2004. CD-ROM

GOLFARI, L. Zoneamento ecológico do Estado de Minas Gerais para reflorestamento. Belo Horizonte, CPFRC, 1975. (Série Técnica, 3)

GHOSH, A.K.; BARBOSA, J. \& SILVA, I.R. An environmental threshold of soil Test $\mathrm{P}$ and degree of $\mathrm{P}$ saturation of Brazilian Oxisols. Clean Soil, Air, Water, 39:421-427, 2011.

GUPTA, G.; BOROWIEC, J. \& OKOH, J. Toxicity identification of poultry litter aqueous leachate. Poultry Sci., 76:13641367, 1997.

HANSEN, J.C.; CADE-MENUM, B.J. \& STRAW, D.G. Phosphorus speciation in manure-amended alkaline soils. J. Environ. Qual., 33:1177-1182, 2004.

HAYES, J.E.; RICHARDSON, A.E. \& SIMPSON, R.J. Components of organic phosphorus in soil extracts that are hydrolysed by phytase and acid phosphatase. Biol. Fert. Soils, 32:279-286, 2000.

HEDLEY, M.J.; STEWART, J.W.B. \& CHAUHAN, B.S. Changes in inorganic and organic soil phosphorus fractions induced by cultivation practices and by laboratory incubations. Soil Sci. Soc. Am. J., 46:970-976, 1982.

INSTITUTO BRASILEIRO DE GEOGRAFIA E ESTATISTICA - IBGE. Pesquisa municipal de produção animal. Brasília, 2003. Available at: <http://www.sidra.ibge.gov.br/bda/ tabela/listabl.asp?z=t\&c=73>. Accessed: Aug. 9, 2005.

KINGERY, W.L.; WOOD, C.W.; DELANEY, D.P.; WILLIAMS, J.C. \& MULLINS, G.L. Impact of long-term land application of broiler litter on environmentally related soil properties. J. Environ. Qual., 23:139-147, 1994.

KOOPMANS, G.F.; CHARDON, W.J.; DOLFING, J.; OENEMA, O.; van der MEER, P. \& RIEMSDŸK, W.H. Wet chemical and phosphorus-31 nuclear magnetic resonance analysis of phosphorus speciation in a sandy soil receiving longterm fertilizer or animal manure applications. J. Environ. Qual., 32:287-295, 2003.

LEYTEM, A.B.; KWANYUEN, P.; PLUMSTEAD, P.W.; MAGUIRE, R.O. \& BRAKE, J. Evaluation of phosphorus characterization in broiler ileal digesta, manure, and litter samples: ${ }^{31} \mathrm{P}-\mathrm{NMR}$ vs. HPLC. J. Environ. Qual., 37:494-500, 2008.
LEYTEM, A.B.; MIKKELSEN, R.L. \& GILLIAM, J.W. Sorption of organic phosphorus compounds in Atlantic Coastal Plain soils. Soil Sci., 167:652-658, 2002.

LINDSAY, W.L. Chemical equilibrium in soils. New York, Wiley, 1979. p. 448.

MAGUIRE, R.; PLUMSTEAD, P.W. \& BRAKE, J. Impact of diet, moisture, location, and storage on soluble phosphorus in broiler breeder manure. J. Environ. Qual., 35:858-865, 2006.

McLEOD, R.V. \& HEGG, R.O. Pasture runoff quality from application of inorganic and organic nitrogen sources. J. Environ. Qual., 13:22-27, 1984.

MURPHY, J. \& RILEY, J.P. A modified single solution method for determination of phosphate in natural waters. Anal. Chim. Acta, 27:31-36, 1962.

NOVAIS, R.F. \& SMYTH, T.J. Fósforo em solo e planta em condições tropicais. Viçosa, MG, Universidade Federal de Viçosa, 1999. 399p.

OGLESBY, K.A. \& FOWNES, J.A. Effects of chemical composition on nitrogen mineralization from green manures of seven tropical leguminous trees. Plant Soil, 143:127-132, 1992.

OLSEN, S.R. \& WATANABE, F.S. A method to determine a phosphorus adsorption maximum of soils as measured by Langmuir isotherm. Soil Sci. Soc. Am. Proc., 21:144$149,1957$.

PEPERZAK, P.; CALDWELL, A.G.; HUNZIKER, R.R. \& BLACK, C.A. Phosphorus fractions in manures. Soil Sci., 87:293-302, 1959.

PREUSCH, P.L.; ADLER, P.R.; SIKORA, L.J. \& TWORKOSKI, T.J. Nitrogen and phosphorus availability in composted and uncomposted poultry litter. J. Environ. Qual., 31:2051-2057, 2002.

RIBAUDO, M.O.; GOLLEHON, N.R. \& AGAPOFF, J. Land application of manure by animal feeding operations: Is more land needed? J. Soil Water Conserv., 62:375-389, 2003.

SAUER, T.J.; DANIEL, T.C.; NICHOLS, D.J.; WEST, C.P.; MOORE, P.A. \& WHEELER, G.L. Runoff water quality from poultry litter-treated pasture and forest sites. J. Environ. Qual., 29:515-521, 2000.

SHARPLEY, A.N. \& MOYER, B. Phosphorus forms in manure and compost and their release during simulated rainfall. J. Environ. Qual., 29:1462-1469, 2000.

SHARPLEY, A.N.; CHAPRA, S.C.; WEDEPOHL, R.; SIMS, J.T.; DANIEL, T.C. \& REDDY, K.R. Managing agricultural phosphorus for protection of surface waters: Issues and options. J. Environ. Qual., 6:33-35, 1994.

SHARPLEY, A.N.; HERRON, S. \& DANIEL, T. Overcoming the challenges of phosphorus-based management challenges in poultry farming. J. Soil Water Conserv., 58:30-38, 2007.

SHARPLEY, A.N. \& MENZEL, R.G. Impact of soil and fertilizer $\mathrm{P}$ on the environment. Adv. Agron., 41:297-324, 1987. 
SHERWOOD, M. \& FANNING, A. Nutrient content of surface run-off water from land treated with animal wastes. In: BROGAN, J.C., ed. Nitrogen losses and surface run-off from land spreading of manures. The Hague, Martinus Nijhoff/W. Junk, 1981. p.5-17.

SHIGAKI, F.; SHARPLEY, A. \& PROCHNOW, L.I. Animalbased agriculture, phosphorus management and water quality in Brazil: Options for the future. Sci. Agric., 63:194209, 2006.

SIMS, J.T.; EDWARD, A.C.; SCHOUMANS, O.F. \& SIMARD, R.R. Integrating soil phosphorus testing into environmentally based agricultural management practice. J. Environ. Qual., 29:60-71, 2000.

SMITH, K.A.; JACKSON, D.R. \& PEPPER, T.J. Nutrient losses by surface run-off following the application of organic manures to arable land. 1. Nitrogen. Environ. Poll., 112:4151, 2001.

SOLOMON, D. \& LEHMANN, J. Loss of phosphorus from soil in semi-arid northern Tanzania as a result of cropping: evidence from sequential extraction and ${ }^{31}$ P-NMR spectroscopy. Eur. J. Soil Sci., 51:699-708, 2000 .

TASISTRO, A.S.; CABRERA, M.L. \& KISSEL, D.E. Water soluble phosphorus released by poultry litter: effect of extraction $\mathrm{pH}$ and time after application. Nutr. Cycl. Agroecosyst., 68:223-234, 2004.

TATE, K.R. \& NEWMAN, R.H. Phosphorus fractions of a climosequence of soils in New Zealand tussock grassland. Soil Biol. Biochem., 14:191-196, 1982.
TURNER, B.L. \& McKELVIE, I.D. A novel technique for the pre-concentration and extraction of inositol hexakisphosphate from soils extracts with determination by phosphorus-31 nuclear magnetic resonance. J. Environ. Qual., 31:466-470, 2002.

TURNER, B.L.; MAHIEU, N. \& CONDRON, L.M. Phosphorus31 nuclear magnetic resonance spectral assignments of phosphorus compounds in soils $\mathrm{NaOH}$-EDTA extracts. Soil Sci. Soc. Am. J., 67:497-510, 2003.

TURRIÓN, M.B.; GALLARDO, J.F.; HAUMAIER, L.; GONZALEZ, M.I. \& ZECH, W. ${ }^{31}$ P-NMR characterization of phosphorus fractions in natural and fertilized forest soils. Ann. For. Sci., 58:89-98, 2001.

USDA-ERS. Confined animal production poses manure management problems. Agric. Outlook, sept., 12-18, 2000.

VADAS, P.A.; MEISINGER, J.J.; SIKORA, L.J.; McMURTRY, J.P. \& SEFTON, A.E. Effect of poultry diet on phosphorus in runoff from soils amended with poultry manure and compost. J. Environ. Qual., 33:1845-1854, 2004.

WILLIAMS, C.M.; BARKER, J.C. \& SIMS, J.T. Management and utilization of poultry wastes. Rev. Environ. Contam. Toxicol., 162:105-157, 1999.

WIMBERLY, J. The status of on-farm litter-to-energy systems in the United States. In: PATTERSON, P.H.; BLAKE, J.P. \& ROBERSON, K.D. NATIONAL POULTRY WASTE MANAGEMENT SYMPOSIUM, 2002. Proceedings... Birmingham, National Poultry Waste Management Symposium Committee, Auburn University, 2002. p.53-57.

YEOMANS, J.C. \& BREMNER, J.M. A rapid and precise method for routine determination of organic carbon in soil. Comm. Soil Sci. Plant Anal., 19:1467-1476, 1998. 